\title{
Effect of the use of Potassium Fertilizer on the Resistance and Growth of Tomato to Bacterial Wilt caused by Ralstonia solanacearum
}

\author{
Anis Rosyidah ${ }^{1}$, Indiyah Murwani² ${ }^{2}$ Bambang Siswadi ${ }^{3}$ \\ 1,2 Agrotechnology Department of Faculty Agriculture - Islamic University of Malang 65144 East Java, Indonesia \\ ${ }^{3}$ Agribusiness Department of Faculty Agriculture - Islamic University of Malang 65144 East Java, Indonesia
}

\begin{abstract}
The research aims to study the effect of sources and doses of potassium fertilizer on the resistance and growth of tomato to bacterial wilt caused by Ralstoniasolanacearum. We conduct experiment in a screen house in Faculty of Agriculture, Islamic University Malang. The research is conducted experimentally using completely randomized block design (RAK) arranged in factorial with three repetition. There are six combinations of treatment. Factor I: source of potassium fertilizer, consists of two levels: $\mathrm{KCl}$ and $\mathrm{K}_{2} \mathrm{SO}_{4}$. Factor II:dose of $\mathrm{K}_{2} \mathrm{O}$, consists of three levels: $50 \mathrm{~kg} \mathrm{ha}^{-1}, 100 \mathrm{~kg} \mathrm{ha}^{-1}$ and $200 \mathrm{~kg} \mathrm{ha}^{-1}$. The inoculation of Ralstonia solanacearum is conducted a week after transplanting. There is significant effect on the use of different sources and doses of potassium fertilizer. As whole, the use of potassium fertilizer originated from $\mathrm{K}_{2} \mathrm{SO}_{4}$ is better than that of $\mathrm{KCl}$ and the magnitude of the increase depends on dose applied. The best result indicates by treatment of the use of $\mathrm{K}_{2} \mathrm{SO}_{4}$ with dose of $200 \mathrm{~kg} \mathrm{ha}^{-1} \mathrm{~K}_{2} \mathrm{O}$ that able to extend the incubation period of 6,27 days, decrease the attack level of 73,15\%, increase the uptake of potassium and leaf chlorophyll of $4,58 \%$ and $7,17 \%$, respectively, and increase root lignin of $3 \%$, whereas total phenol is decreased of 27,27\% compare to the use of $\mathrm{KCl}$ in the same dose.
\end{abstract}

Keywords-Potassium fertilizer, Source, Dose, Plant resistance, Ralstonia solanacearum.

\section{INTRODUCTION}

Tomato is one of superior horticultural commodities in Indonesia and has a promising economic prospect. Therefore, it needs serious handling, especially, in terms of increasing its yield and fruit quality. The projection of national tomato demand for 2014-2019 is around 970.499 - $1,107,168$ ton, whereas tomato product by 2013 was only 922,780 ton with average productivity of 16.61 t.ha $^{-1}$ (Bureau of Statistics and Directorate General of Horticulture, 2014).

One of obstacles in the low production of tomato is the occurrence of wilt disease caused by Ralstonia solanacearum bacteria, which is a threat for hot climate areas or areas with warm rainy season. Result of field observation shows that the disease has caused the loss of fresh fruit in approximately $7.1-63.7 \%$ (Rosyidah et al., 2014). It is unfavorable for farmers since the investment for production cost is high.

Various efforts of controlling the disease have been conducted, such as the use of organic material from chicken manure (Rosyidah, A., 2012), the use of cabbage family as bio-fumigant, and the use of resistance variety (Rosyidah et al., 2014). Another effort is the use of potassium fertilizer with appropriate source and dose. This effort is another alternative to increase plant resistance against environmentally friendly disease.

Tomato plant absorbs large amount of potassium element in approximately $1-5 \%$ of plant's dry weight (Chen and Gabelman, 2000). Potassium plays important role in plant metabolism (Farhad et al., 2010), helps in the formation of protein, carbohydrate, enzyme activity, regulation of osmotic, water use efficiency, translocation of photosynthate (McKenzie, 2001), stimulate the development of root and increase the size of fruit (Marsono and Sigit, 2001), and increase the transportation of sugar and acid to storage organ (Bernardi et al., 2013). The application of potassium could increase the formation of thick lignin compound; therefore, wall cell will be stronger and able to protect plant from pathogen interference (Fageria et al., 2009).

Potassium fertilizer mostly used in Indonesia is muriate of potash $(\mathrm{KCl})$ containing about $60 \%$ of $\mathrm{K}_{2} \mathrm{O}$. Recently, however, there is a development in the use of potassium sulphate $\left(\mathrm{K}_{2} \mathrm{SO}_{4}\right)$. Some research found that the incident of disease is higher when potassium fertilizer used is originated from $\mathrm{KCl}$, whereas potassium sulphate is proven to improve some characteristics of quality of various vegetable products (Gunadi, 2009). At present, the role of potassium in increasing plant resistance, especially in tomato, has not been studied.

The aim of the research is to study the effect of combination of source and dose of potassium fertilizer on 
the resistance and growth of tomato toward bacteria wilt caused by Ralstonia solanacearum.

\section{MATERIALS AND METHODS}

The research was conducted experimentally in a screen house in Faculty of Agriculture, Islamic University Malang in April - July, 2016. The altitude of the location was 460 above sea level. Type of soil is loam. Air temperature is around $22.5{ }^{\circ} \mathrm{C}-25.5^{\circ} \mathrm{C}$ with air humidity of $80 \%-86 \%$. The research was conducted experimentally using completely randomized block design (RAK) arranged in factorial with three repetition. There were six combinations of treatment. Factor I: source of potassium fertilizer, consisted of two levels: $\mathrm{KCl}$ and $\mathrm{K}_{2} \mathrm{SO}_{4}$. Factor II was dose of $\mathrm{K}_{2} \mathrm{O}$, consisted of three levels: $50 \mathrm{~kg} \mathrm{ha}^{-1}, 100 \mathrm{~kg} \mathrm{ha}^{-1}$ and $200 \mathrm{~kg} \mathrm{ha}^{-1}$. Each treatment consisted of ten sample plants.

Tomato seeds from Lentana variety were planted in seeding basin with media of soil + sand + compost that previously sterilized with hot steam for 3 hours with ratio of $1: 1: 1$. At the age of 10 days, plant's seedlings were transferred to seedling glass, one seedling per glass.

Growing media used weresoil:sand:organic material of chicken manure $(\mathrm{C} / \mathrm{N}=12)$ (ratio of $2: 1: 1$ ) that previously sterilized with hot steam for 3 hours. Growing media of $8 \mathrm{~kg}$ was put into a polybag. The transplanting of tomato seedling was conducted when the seedling has height of $10 \mathrm{~cm}$ and 4 leaves.

Inorganic fertilizers applied were SP-36 and it was applied on 3 days after transplanting with dose of 150 $\mathrm{kg} / \mathrm{Ha}$ and Urea on 7 days after transplanting with dose of $150 \mathrm{~kg} \mathrm{Ha}^{-1}$. The application of $\mathrm{KCl}$ and $\mathrm{K}_{2} \mathrm{SO}_{4}$ fertilizers was conducted at the age of 7 days after transplanting with dose in accordance with the treatment.

The isolate of $R$. solanacearum used was the result of isolation of tomato plant attacked by $R$. solanacearum in Donowarih Village, Karangploso, Malang. The purification isolation and propagation of $R$. solanacearum was conducted using media of TZC (2,3,5-triphenyl tetrazolium chloride). Population density for inoculation was $2.78 \times 10^{8}$ cfu. $\mathrm{mL}^{-1}$ measured with spectrophotometer in OD 600. Plants at the age of 1 week after transplanting were inoculated with $R$. solanacearum with concentration of $10^{8} \mathrm{cfu} / \mathrm{ml}$ of $20 \mathrm{ml}$ by wounding the plant roots using scalpel.

Observation was conducted on: incubation period of the disease, level of disease attack (Sinaga, 2003), potassium uptake in leaves (through extraction using $\mathrm{NH}_{4} \mathrm{Oac}$ ), root lignin (Acid detergent fiber method), total phenol (FolinDenis method), level of leaf chlorophyll (SPAD) and plant height.

In order to see the influence of treatments on observation conducted, data of observation result was statistically analyzed based on analysis of variance (ANOVA) and followed by Least Significance Difference test in confidence level of $95 \%$ to see their significances.

\section{RESULT ANDDISCUSSION}

The status of soil fertility used in the experiment is presented in Table 1. The content of carbon (C), nitrogen $(\mathrm{N})$, and $\mathrm{C} / \mathrm{N}$ ratio is classified as low. Phosphor $(\mathrm{P})$ and potassium (K) are classified as medium and low, respectively, whereas, cation exchange capacity (KTK) is classified as medium.

Incubation period and level of attack of R. solanacearum disease

Based on research result (Table 2), it can be seen that there was a significant interaction $(p<0.05)$ in the treatment of the use of potassium fertilizer sources and doses on incubation period of the disease and the attack level of bacterial wilt disease.

Based on Table 2, it is known that the use of different potassium fertilizer sources and doses resulted in different disease incubation period and level of attack. The incubation period of the disease was ranged from 16.21 to 25.74 days after inoculation. Level of attack of the disease was ranged from $6.22 \%$ to $12.21 \%$ at the age of 35 days after transplanting. The application of potassium fertilizer of $\mathrm{K}_{2} \mathrm{SO}_{4}$ is better than those of $\mathrm{KCl}$. It is estimated that it is due to the content of $\mathrm{SO}_{4}$ in potassium sulphate fertilizer since one of the functions of sulfur $(\mathrm{S})$ is to reduce the attack of the disease (Tisdale et al., 1990). The higher the dose of potassium fertilizer $\left(200 \mathrm{~kg} \mathrm{ha}^{-1} \mathrm{~K}_{2} \mathrm{O}\right)$ applied, the longer the incubation period and the lower the attack level caused by $R$. solanacearum pathogen. It happens because the initial content of $\mathrm{K}$ element in soil used for the experiment was low. With the addition of potassium of $200 \mathrm{~kg} \mathrm{ha}^{-1} \mathrm{~K}_{2} \mathrm{O}$ in the treatment gives sufficient nutrient and good plant resistance. One of the function of $\mathrm{K}$ element is to improve plant resistance by strengthening plant tissues and thickening epidermic wall. Nurhayati (2008) stated that potassium in plant plays role in the formation of protein and carbohydrate as well as in the increasing of resistance against pathogen.

Potassium uptake, root lignin and total phenol

Research result shows that there was significant interaction $(p<0.05)$ in the treatment of the use of potassium fertilizer sources and doses on potassium uptake, root lignin and total phenol (Tabel 3).

Based on Table 3, it is known that the use of different potassium fertilizer sources and doses resulted in different potassium uptake, root lignin level and total phenol level of plant. The application of potassium fertilizer $\mathrm{K}_{2} \mathrm{SO}_{4}$ was better than that of $\mathrm{KCl}$. In addition, the higher the dose of potassium fertilizer $\left(200 \mathrm{~kg} \mathrm{ha}^{-1} \mathrm{~K}_{2} \mathrm{O}\right)$ applied, 
the higher the leaf potassium intake and root lignin level and the lower the level of total phenol.

Result of observation on the level of potassium uptake in leaves shows that bigger potassium uptake in leaves will increase availability status of potassium in plant organs. The sufficiency of potassium has function in increasing the status of plant defense to improve damage caused by pathogen since plant is able to increase the strength of its cell wall. Hardter, R (2003) and Pervez, H et al., (2007) add that the sufficient level of potassium in plant could increase the strength of paddy's stem and stalk due to the increase of its resistance. It is also explained that plant stomata and lenticel work well if sufficient potassium is exist. When pathogen invaded the plant, stomata and lenticel have the ability to close quickly. Potassium is also able to improve the work of enzyme for plant metabolism. The sufficiency of potassium in plant will increase the synthesis of molecular compounds with high molecular weight (protein, starch, cellulose) thus decreasing the synthesis of molecular compounds with low molecular weight, such as: organic acid, amino acid, and amide in plant tissues. It is the decrease of the synthesis of compounds with low molecular weight that able to increase plant resistance against pathogen infection (Marschner, P., 2012; Mengel, K., 2001). Potassium element also plays role in lignification of sclerenchyma tissue (Fageria et al., 2009). Therefore, the sufficiency of potassium could increase the formation of thicker lignin compound; thus, cell wall is stronger and able to protect plant from external disturbance.

Observation on total phenol shows that the increasing of potassium dose applied will decrease the level of total phenol. In other words, the lower the doses of potassium fertilizer applied, the bigger the level of attack; therefore, a tendency of the increase in phenol compound level. The increase in phenol compound is the reaction of plant toward infection of $R$. Solanacearum pathogen and root wounding before pathogen inoculation. Pieterse et al., (2009) stated that the increase of plant resistance through SAR (Systemic Acquired Resistance) occurs after local pathogen infection in plant; the infected plant, then, activates genes that play role in the resistance to produce chemical compounds for plant resistance, such as salicylate. When the plant has the resistance, it will be able to protect itself if another pathogen exists; thus, pathogen infection will not be developed. According to Goodman et al., (1986), plant tissue infected by pathogen indicates a change in metabolic pattern, including, activating peroxide and other phenoloxidase enzymes. It is in line with Matern et al. (1995) and De Ascensao et al. (2003) stated that great phenol synthesis will occur if plant is attacked by pathogen. Agrios (2005) stated that pathogen microorganism causing mechanical and chemical damages will stimulate plant to produce toxin compound against pathogen (phytoalexin). Plants need peroxide enzyme to produce resistance compounds, such as lignin, chitin, and various compounds that build cell wall (Hallman, 2001). Further, Bruce et al. (1989) stated that peroxide is another component in the initial response of plant to pathogen attack and plays key role in the biosynthesis of lignin that limit the area of pathogen distribution.

\section{Leaf chlorophyll and plant height}

Research result shows that there was significant interaction $(p<0.05)$ on the treatment of the use of potassium fertilizer sources and doses on the content of leaf chlorophyll. Regarding observation on final plant height, it shows no interaction between potassium fertilizer sources and doses tested (Figure 1A and 1B).

Treatment of the application of $\mathrm{K}_{2} \mathrm{SO}_{4}$ shows more chlorophyll content than that of $\mathrm{KCl}$. It is likely due to the content of sulfur in $\mathrm{K}_{2} \mathrm{SO}_{4}$ fertilizer. Sulfur is the main element in the formation of leaf chlorophyll that closely related to photosynthesis process and takes part in various metabolism reactions, such as carbohydrate, fat and protein (Tisdale et al., 1990). The increase in potassium fertilizer dose applied will increase chlorophyll content. It is due to the sufficiency of potassium in the plant that will increase the work of enzymes thus increasing the activation of plastid in leaf, synthesis of protein, photosynthesis and stomata movement. It results in the increase in the production of leaf chlorophyll. The optimum availability of potassium in leaf will make the leaf to be more efficient in the photosynthesis and plant will be more resistance and tolerance.

\section{CONCLUSIONS}

In the research, we report the effect of the use of potassium fertilizer on the resistance and growth of tomato to bacterial wilt caused by $R$. solanacearum. The result can be summarized as follow: the effect of the interaction is significant in the component of resistance but not in the observation on plant height. Treatment of $\mathrm{K}_{2} \mathrm{SO}_{4}$ and doses of potassium fertilizer $\left(200 \mathrm{~kg} \mathrm{ha}^{-1} \mathrm{~K}_{2} \mathrm{O}\right)$ is the best as indicated by longer incubation period of 6.27 days, decrease in the level of attack of $73.15 \%$, increase in potassium uptake and chlorophyll in leaf of $4.58 \%$ and $7.17 \%$, respectively and the increase in root lignin of $3 \%$ and decrease in phenol of $27.27 \%$ compare to the use of $\mathrm{KCl}$ in the same dose.

\section{ACKNOWLEDGEMENTS}

The authors would like to thank the Directorate General of Ministry of Research, technology and higher education for the support for Competitive Research Grant, Agrotechnology Department of Faculty Agriculture - 
Islamic University of Malang, Laboratory of Biology Faculty of Science Brawijaya University and all parties who help the research.

\section{REFERENCES}

[1] Agrios, G.N. 2005. Pengantar Ilmu Penyakit Tumbuhan. Gajahmada University Press. Yogyakarta. 713 p.

[2] Bruce, RJ., West CA. 1989. Elicitation of Lignin Biosynthesis and Isoperoxidase Activity by Pectic Fragments in Suspension Cultures of Cluster Bean. Plant Physiol. 91: 889-897

[3] BPS dan Dirjen Hortikultura, 2014. Produksi Tomat. www.bps.go.id. Diakses tanggal 25 Oktober 2015.

[4] Chen, J., W.H. Gabelman. 2000. Morphological and Physiological Characteristics of Tomato Roots Assosiated with Potassium-acquisition Efficiency. Scientia Horticulturae 83:213-255.

[5] De Ascensao, A.F.R.D.C. and Dubrey, I.A. 2003. Soluble and Wall-Bound Phenolic Polymers in Musa acuminata Roots Exposed to Elicitors From Fusarium oxysporum f.sp. cubens. Phytochemistry 63, 679-686.

[6] Fageria, NK, M.P.B. Filho, and J.H.C. Da Costa. 2009. Potassium in The Use of Nutrients in Crops Plant. CRC Press Taylor \& Francis Group, Boca Raton. London. New York. Pp.131-163

[7] Farhad, I.S.M., M.N. Islam, S. Hoque, and M.S.I. Bhuiyan. 2010. Role of Potassium and Sulphur on The Growth, Yield, and Oil Content of Soybean ( Glycine $\max$ L.) Ac. J. Plant Sci. 3(2):99-103

[8] Gunadi, N. 2009. Kalium Sulfat dan Kalium Klorida Sebagai Sumber Pupuk Kalium pada Bawang Merah. J. Hortikultura. 19(2):174-185

[9] Hardter, R. Potassium and Biotic Stress of Plants. 2003. In Feed the Soil to Feed the People: The Role of Potash in Sustainable Agriculture . Johnston, A.E., Ed.. International Potash Institute: Basel, Switzerland. pp. 345-362.
[10] McKenzie, R. 2001. Potassium Fertilizer Application in Crop Production. http://www.agric.gov.ab.ca/universalpages/ includes/docheader.map. [14 Maret 2015].

[11] Marschner. 2012. Mineral Nutrition of Higher Plants , 3rd ed.; Academic Press: London. pp. 178-189.

[12] Matern, U., Grimmig, B., and Kneusel, R.E. 1995. Plant Cell Wall Reinforcement in the DiseaseResistance Response: Molecular Composition and Regulation. Canandian Journal of Botany 73, p. 511S517.

[13 Mengel, K. Principles of Plant Nutrition , 5th ed.; Kluwer Academic Publishers: Dordrecht, the Netherlands, 2001; pp. 481-509.

[14] Nurhayati, 2008. Pengaruh Kalium Pada Ketahanan Kacang Tanah Terhadap Bercak Daun Cercospra. J. Penelitian. pp. 446-450

[15] Pervez, H., Ashraf, M., Makhdum, M.I.; Mahmood, T. 2007. Potassium Nutrition of Cotton (Gossypium hirsutum L.) in Relation to Cotton Leaf curl Virus Disease in Andisols. Pak. J. Bot., 39: 529-539.

[16] Pieterse, C.M.J., A. Leon-Reyes, S. Van der Ent dan S. C M Van Wees. 2009. Networking by SmallMolecule Hormones in Plant Immunity. Nature Chemical Biology Biology 5, 308-316 (Published online: 26 April 2009)

[17]Rosyidah, A., Djuhari. 2014. The Increase in Effectiveness of Broccoli waste as Bio - Fumigant to Control Ralstonia solanacearum on Tomato (Solanum lycopersicum L.). Journal of Biology Agriculture and Healthcare. 4(24);85-90

[18]Rosyidah, A. Yekti,S.R., Adri, B., Bambang S. 2012. Pemanfaatan Bahan Organik dan Trichoderma harzianum dalam Bentuk Tepung untuk Mengendalikan Layu Bakteri Ralstonia solanacearum pada Kentang (Solanum tuberosum L.). J.Primordia. 8(2):144-153

[19] Tisdale, S. L, Nelson W. L., and Beaton J. D. 1990. Soil fertility and fertilizers 4 th Ed. Maxwell Mc milan Publishing. Singapura. $52-92$

Table.1: Status of soil fertility used as growing media

\begin{tabular}{ccccccr}
$\mathrm{pH}$ & $\mathrm{C}$ & $\mathrm{N}$ & $\mathrm{C} / \mathrm{N}$ & $\mathrm{P}$ & $\mathrm{K}$ & $\mathrm{KTK}$ \\
\hline$(\mathrm{H} 2 \mathrm{O})$ & $\ldots . \%$ & $\ldots$ & & (Bray) & $\mathrm{me} / 100 \mathrm{~g}$ & $\mathrm{me} / 100 \mathrm{~g}$ \\
\hline \multicolumn{8}{c}{} \\
\hline 5,4 & 0,98 & 0,13 & 8 & 417,1 & 0,29 & 22,38 \\
\hline \multicolumn{2}{l}{ Source: Laboratory of Soil, Faculty of Agriculture, University of Brawijaya, 2016}
\end{tabular}


Table.2: Incubation period and attack level of the disease due to the interaction of potassium fertilizer sources and doses

\begin{tabular}{lcc}
\multicolumn{1}{c}{ Treatments } & $\begin{array}{c}\text { Incubation period } \\
\text { (days) }\end{array}$ & $\begin{array}{c}\text { Disease incidence } \\
(\%)\end{array}$ \\
\hline $\mathrm{KCl}$ & $16,21 \mathrm{a}$ & $12,21 \mathrm{e}$ \\
$50 \mathrm{~kg} / \mathrm{ha} \mathrm{K2O}$ & $17,58 \mathrm{~b}$ & $11,10 \mathrm{~d}$ \\
$100 \mathrm{~kg} / \mathrm{ha} \mathrm{K2O}$ & $19,47 \mathrm{c}$ & $10,77 \mathrm{~d}$ \\
$200 \mathrm{~kg} / \mathrm{ha} \mathrm{K2O}$ & $22,23 \mathrm{e}$ & $9,25 \mathrm{c}$ \\
$\mathrm{K} 2 \mathrm{SO} 4$ & $21,13 \mathrm{~d}$ & $8,80 \mathrm{~b}$ \\
$50 \mathrm{~kg} / \mathrm{ha} \mathrm{K2O}$ & $25,74 \mathrm{f}$ & $6,22 \mathrm{a}$ \\
$100 \mathrm{~kg} / \mathrm{ha} \mathrm{K2O}$ & & 0,41 \\
$200 \mathrm{~kg} / \mathrm{ha} \mathrm{K2O}$ & 0,60 & 0,41 \\
\hline LSD 5\% & &
\end{tabular}

Note: Numbers with different letters in the same column shows significantly different in Least

Significance Difference test with level of $5 \%$

Table.3: Potassium uptake, root lignin and total phenol due to the interaction of potassium fertilizer sources and doses

Treatments

Potassium uptake

(\%)

$\mathrm{KCl}$

$50 \mathrm{~kg} / \mathrm{ha} \mathrm{K} 2 \mathrm{O}$

$100 \mathrm{~kg} / \mathrm{ha} \mathrm{K} 2 \mathrm{O}$

$200 \mathrm{~kg} / \mathrm{ha} \mathrm{K} 2 \mathrm{O}$

$\mathrm{K} 2 \mathrm{SO} 4$

$50 \mathrm{~kg} / \mathrm{ha} \mathrm{K} 2 \mathrm{O}$

$100 \mathrm{~kg} / \mathrm{ha} \mathrm{K} 2 \mathrm{O}$

$200 \mathrm{~kg} / \mathrm{ha} \mathrm{K} 2 \mathrm{O}$

$\begin{array}{ll}1,087 & a \\ 1,114 & b \\ 1,141 & c \\ & \\ 1,114 & b \\ 1,157 & d \\ 1,165 & \text { e }\end{array}$

0,0087
Root lignin

(\%)

$\begin{array}{ll}15,01 & a \\ 15,96 & b \\ 16,03 & c \\ & \\ 15,98 & b \\ 16,06 & c \\ 16,46 & d\end{array}$

Total phenol (mg/g)

$\begin{array}{ll}1,393 & \mathrm{a} \\ 1,430 & \mathrm{ab} \\ 1,453 & \mathrm{ab} \\ & \\ 1,513 & \mathrm{c} \\ 1,593 & \mathrm{~d} \\ 1,833 & \mathrm{e}\end{array}$

LSD 5\%

0,03

0,056

Note: Numbers with different letters in the same column shows significantly different in Least Significance Different

Test in level of $5 \%$
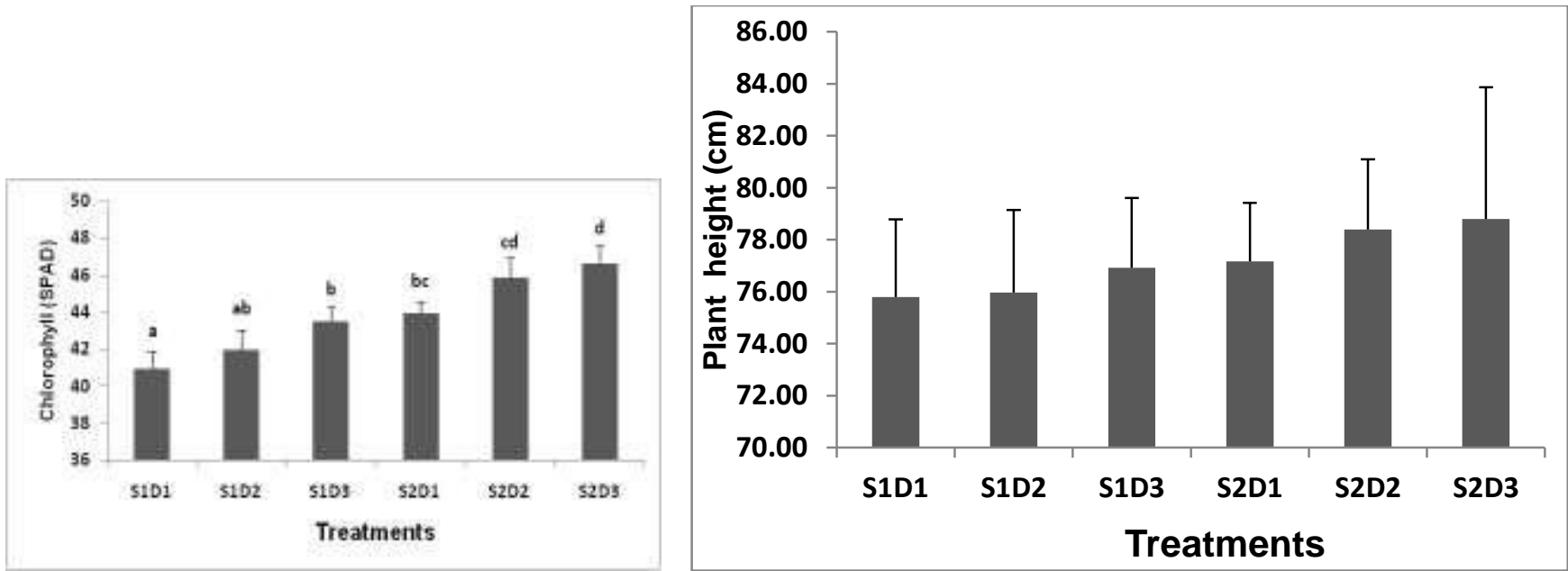

Fig.1: $A$ and B. The interaction of the effect of potassium fertilizer sources and doses on leaf chlorophyll (A) and plant height

(B).S1D1 = KCl $40 \mathrm{~kg} \mathrm{ha}^{-1} \mathrm{~K}_{2} \mathrm{O}, \mathrm{S} 1 \mathrm{D} 2=\mathrm{KCl} 80 \mathrm{~kg} \mathrm{ha}^{-1} \mathrm{~K}_{2} \mathrm{O}, \mathrm{S} 1 \mathrm{D} 3=\mathrm{KCl} 160 \mathrm{~kg} \mathrm{ha}^{-1} \mathrm{~K}_{2} \mathrm{O}, \mathrm{S} 2 \mathrm{Dl}=\mathrm{K}_{2} \mathrm{SO}_{4} 40 \mathrm{~kg} \mathrm{ha}^{-1} \mathrm{~K}_{2} \mathrm{O}$, $\mathrm{S} 2 \mathrm{D} 2=\mathrm{K}_{2} \mathrm{SO}_{4} 80 \mathrm{~kg} \mathrm{ha}^{-1} \mathrm{~K}_{2} \mathrm{O}, \mathrm{S} 2 \mathrm{D} 3=\mathrm{K}_{2} \mathrm{SO}_{4} 160 \mathrm{~kg} \mathrm{ha}^{-1} \mathrm{~K}_{2} \mathrm{O}$ 